\title{
PRIVATE ECONOMIC COERCION AND THE CIVIL RIGHTS ACT OF $1957^{*}$
}

A RECENT attempt by the federal government to enjoin private economic retaliation against Negroes who registered to vote in Haywood County, Tennessee, ${ }^{1}$ raises questions concerning the scope and effectiveness of the Civil Rights Act of 1957.2 The Supreme Court has long considered voting "a right secured by the Constitution" against racially inspired deprivations. ${ }^{3}$ But prior to the enactment of the 1957 statute there was no effective means by which the rights of Negroes to register and vote in federal elections could be enforced. Between 1866 and 1875, Congress, pursuant to its power to regulate "the times, places, and manner of holding [federal] elections" 4 and to enforce the 15th Amendment's proscription against state abridgment of voting rights on racial grounds, ${ }^{5}$ enacted a number of statutes directed at the protection of Negro voting rights. ${ }^{6}$ These statutes declared, inter alia, ${ }^{7}$ that no citizen

*United States v. Beaty, 288 F.2d 653 (6th Cir. 1961).

1. United States v. Beaty, 288 F.2d 653 (6th Cir. 1961).

2. 71 Stat. 637 (1957), 42 U.S.C. § 1971 (b) \& (c) (1958).

3. United States v. Classic, 313 U.S. 299, 315 (1941). See also Ex parte Yarbrough, 110 U.S. 651, 657, 661 (1884); Wiley v. Sinkler, 179 U.S. 58, 62 (1900); Swafford v. Templeton, 185 U.S. 487 (1902); United States v. Mosley, 238 U.S. 383 (1915).

Although the Constitution deals in many places with voting, it is quite oblique about granting the right to vote in federal elections. Article I, $\S 2$ and Amendment XVIII, $\S 1$, dealing respectively with the election of Representatives and Senators, leave the determination of voter qualifications to the States. The equal protection clause of the XIV Amendment protects voters from state interference with the equality of opportunity to vote in any election. Amendment XV protects citizens from being denied the right to vote by any State because of race, color, or previous condition of servitude. Section 2 of Amendment XIV, however, seems to assume the existence of a "right to vote." Article I, $\S 4$ gives to the Congress the ultimate say in determining the times, places and manner of holding Congressional elections. See Ex parte Siebold, 100 U.S. 371 (1879) ; United States v. Gale, 109 U.S. 65 (1883) ; Ex parte Clarke, 100 U.S. 399 (1879). Amendment XIX forbids denial of the right to vote because of sex.

4. Article I, $\S 4$ gives Congress the power to protect the federal elections from interference by private persons and states. Ex parte Yarbrough, 110 U.S. 651 (1884); In re Coy, 127 U.S. 731 (1888) ; Guinn v. United States, 238 U.S. 347 (1915) ; Rice v. Elmore, 165 F.2d 387 (4th Cir. 1947) ; United States v. McElveen, 180 F. Supp. 10 (E.D. La. 1960), aff'd sub nom. United States v. Thomas, 362 U.S. 58 (1960); United States v. Association of Citizens Councils of Louisiana, 187 F. Supp. 846 (W.D. La. 1960).

5. Amendents XIV and XV have been held to require state action and neither amendment reaches the conduct of private persons acting in a wholly private capacity. Civil Rights Cases, 109 U.S. 3 (1883) ; United States v. Cruikshank, 92 U.S. 542 (1875). Private persons, however, may be considered as acting under color of state authority when they are acting in concert with the state. Cf. Burton v. Wilmington Parking Authority, 365 U.S. 715 (1961).

6. See Report of Prestient's Committee on Civil Rights To Secure These Rights 104-06 (1947) [hereinafter cited as To Secure These Rughts]; United States CoMmission on Civil Rights, 1961 Civir Rights Report 73-75 [hereinafter cited as CiviL 
could be denied the right to vote in any election because of race and made any attempt at such denial a misdemeanor, subject to private injunctive and compensatory relief. 8

The courts, in a series of decisions between 1873 and 1903, circumscribed these statutes ${ }^{9}$ by limiting their application to federal elections, ${ }^{10}$ by declaring some of the remedies unconstitutional, ${ }^{11}$ by construing the statutes to proscribe only those acts which were committed under color of law, ${ }^{12}$ by requiring the exhaustion of state administrative remedies as a precondition to the invocation of the federal statute, ${ }^{13}$ and by denying disenfranchised Negroes the privilege of suing as a class. ${ }^{14}$

Rights Report] ; Konvitz, A Century of Civil Rights 41-101 (1961); Carr, Federal Protection of Civil Rights (1947).

7. 14 Stat. 27 (1866), 42 U.S.C. $\$ \S 1982,1987,1989-92$ (1958); 18 U.S.C. $§ 242$ (1958) ; 16 Stat. 140 (1870), 18 U.S.C. $\$ 241$ (1958) ; 42 U.S.C. $\$ \$ 1988,1989-91$ (1958) ; 16 Stat. 433 (1871) ; 17 Stat. 13 (1871), 42 U.S.C. $\$ \$ 1983,1985$, 1986 (1958); ch. 114, 18 Stat. 335 (1875).

8. 16 Stat. $140, \S 1$ declared the right to vote. Of the remedy sections, $\S 5$ is of particular interest. It provided:

That if any person shall prevent, hinder, control, or intimidate, or shall attempt to prevent, hinder, control, or intimidate, any person from exercising or in exercising the right to suffrage, to whom the right of suffrage is secured or guaranteed by the fifteenth amendment ... by means of ... depriving such person of employment or occupation, or of ejecting such person from rented house, lands, or other property, or $b y$ threats of refusing to renew leases or contracts for labor ... such person ... shall be deemed guilty of a misdemeanor.... (Emphasis added.)

Section 5 was subsequently held unconstitutional by James v. Bowman, 190 U.S. 127 (1903) on the theory "that a statute which purports to punish purely individual action cannot be sustained as an appropriate exercise of the power conferred by the Fifteenth Amendment upon Congress to prevent action by the State..." Id. at 139. It was subsequently repealed by 35 Stat. 1153 (1909).

9. Congress also revised two sections: $\S 2,17$ Stat. 13 (1871), revised by 42 U.S.C. $\S$ 1985 (1958) and $\S 16,16$ Stat. 144 (1870), as amended, 42 U.S.C. $§ 1981$ (1958).

10. Slaughter-House Cases, 16 Wall. (83 U.S.) 36 (1873).

The significances of the distinction between the vote in State and federal elections lies in the fact that the federal protective power does not extend to purely private acts depriving people of their opportunity to vote for state or local officials. See note 3 supra and CIVIr RIGHTS REPORT at 16-17.

11. See United States v. Reese, 92 U.S. 214 (1876), declaring unconstitutional $\$ \S 3,4$, 16 Stat. 140 (1870) ; Civil Rights Cases, 109 U.S. 3 (1883), declaring unconstitutional §§ 1, 2, 18 Stat. 335 (1875); and James v. Bowman, 190 U.S. 127 (1903), declaring unconstitutional § 5, 16 Stat. $140(1870)$.

12. United States v. Cruikshank, 92 U.S. 542 (1875) ; United States v. Harris, 106 U.S. 629 (1882); Civil Rights Cases, 109 U.S. 3 (1883). See also United States v. Raines, 172 F. Supp. 552 (M.D. Ga. 1959), for its discussion of this question.

13. Carson v. Warlick, 238 F.2d 724 (4th Cir. 1956), cert. denicd, 353 U.S. 910 (1957) ; Peay v. Cox, 190 F.2d 123 (5th Cir. 1951) and not to state judicial remedies. See Lane v. Wilson, 307 U.S. 268, 274 (1939).

14. Jinks v. Hodge, 11 F.R.D. 346 (E.D. Tenn. 1951) (the Civil Rights Acts do not permit class actions for damages or injunction because they grant only personal 
It should have been apparent to any Congressman contemplating the plight of the disenfranchised Negro after the Second World War that the complex of statutes then in effect ${ }^{15}$ provided little hope for enforcement of Negro voting rights in the vast twelve state area commonly known as the "black belt." The "black belt" is a poor agricultural expanse populated by more Negroes than whites, where cotton and tobacco are still grown extensively on farms owned by whites and worked by Negro sharecroppers. ${ }^{17}$ These croppers are generally uneducated, ${ }^{18}$ impoverished, ${ }^{19}$ unable to obtain legal assistance, ${ }^{20}$ under-represented on jury panels, ${ }^{21}$ and dependent upon the white landlord for economic survival. ${ }^{22}$ The economically dependent Negro could not realistically have been expected individually to assert and litigate his right to register at the risk of displeasing his landlord. ${ }^{23}$ The requirement that all state remedies be exhausted before the federal statutes could be invoked contributed to the already prohibitive expense ${ }^{24}$ of bringing a lawsuit which, in all probability, would be futile. ${ }^{25}$ And the refusal of courts to entertain class suits denied the disenfranchised Negroes a device which might have mitigated some of these difficulties. ${ }^{26}$ Moreover, the federal government was limited in its attempt to enforce the right of the Negro to the commencement of criminal prosecutions ${ }^{27}$ which, in addition to being ill suited to the widespread enforce-

rights); Mitchell v. Wright, 62 F. Supp. 580 (M.D. Ala. 1945), rev'd on other grounds, 64 F.2d 924, cert. denied, 329 U.S. 733 (1946); compare Reddix v. Lucky, 252 F.2d 930 (5th Cir. 1958) ; Hunt v. Arnold, 172 F. Supp. 847 (N.D. Ga. 1959).

15. The remnants of the original civil rights legislation after the Second World War might be summarized in the following manner: 1) The section which is merely declaratory of rights and carries no remedy, 16 Stat. 140 (1870). This section was reenacted as 71 Stat. 637 (1957), 42 U.S.C. $\$ 1971$ (a) (1958); 2) Those sections which gave remedies in the form of civil causes of action. 17 Stat. 13, 15 (1871), 42 U.S.C. $\$ \S 1983,1985$, $1986(1958)$; 3) Those sections which impose criminal sanctions. 18 U.S.C. $\$ \$ 241,242$ (1958) ; 4) Those sections which are procedural. 28 U.S.C. $\S \S 1343,1443$, (1958).

See Crvil Rights Report 73-75, Comment, 56 Mich. L. Rev. 619, 623-625 (1958); Konvitz, A Century of Civil Rughts 65-72 (1961).

16. See Cinl Rights Report 143-46.

17. See id. at 146-50, 358-61.

18. See id. at 354-55.

19. See id. at 357 .

20. See, e.g., N.Y. Times, Oct. 31, 1961, p. 20, col. 2. Cf. N.Y. Times, Sept. 14, 1960, p. 1 , col. 1 .

21. See Putzel, Federal Civil Rights Enforcement: A Current Appraisal, 99 U. PA. L. Rev. 439, 449 (1951); Note, 47 Colun. L. Rev. 76, 96 (1947).

22. See Civil Rights Report 190-91.

23. See note 14 supra; Price, The Negro and the Baliot in the Soutr 43-44 (1959).

24. Civil Rights Report 75 ; Comment, 43 CoRnell L.Q. 661, 665 (1958).

25. To Secure These Rights 104-05 ("This early program was largely a failure."); Testimony of Hon. Emanuel Celler at the Hearings on H.R. 6127 Before the House Committee on Rules, 85th Cong., 1st Sess. 2 (1957) [hereinafter cited as Fearings].

26. See note 23 sipra.

27. 18 U.S.C. $\S \S 241,242,595$ (1958). 
ment of voting rights, ${ }^{28}$ were essentially unobtainable because the economic situation in the area lent itself to a pattern of effective but subtle coercion directed at maintaining the white character of the electorate, ${ }^{29}$ and because the predominantly white juries were reluctant to return convictions..$^{30}$ It is not surprising therefore that in 1950 despite the continued maintenance of the Reconstruction civil rights laws on the statute books of our nation, 13 of the 158 counties comprising the "black belt" had no Negroes registered, and 79 others had fewer than 10 per cent of the eligible Negroes registered. ${ }^{31}$

In an effort to remedy these defects Congress, in 1957, passed a new Civil Rights Act ${ }^{32}$ which declares, inter alia, that "no person, whether acting under color of law or otherwise, shall intimidate, threaten, coerce or attempt to intimidate, threaten or coerce any other person for the purpose of interfering with the right of such other person to vote [in federal elections]."33 The new statute provides further that "Whenever any person has engaged or there are reasonable grounds to believe that any person is about to engage in any act or practice which would deprive any other person [of such rights], the Attorney General may institute . . a civil action or other proper proceedings for preventative relief, including an application for a permanent or temporary injunction, restraining order, or other order."34 Actions may be brought under the new statute without regard for exhaustion by plaintiff of administrative or other remedies. ${ }^{\mathbf{3 5}}$

By authorizing the Attorney General to institute equitable proceedings, Congress manifested an intent to alleviate the expenses and fear of reprisals which traditionally accompanied private actions, to facilitate large scale proceedings affecting many potential voters, and to deny to local juries the power to thwart broad national policy.

28. See To Secure These Rights 152, 160; Civil Rights Refort 228 n.18.

29. See notes 17-23 supra and accompanying text.

30. See To Secure These Rughts at 126-33; Comment, 44 Calif. L. Rev. 887, 893 (1956) ; H.R. 291, U.S. CoNG. \& Ad. News 1979 (1957) (letter from Attorney General Herbert Brownell) [hereinafter cited as House Report] See, e.g., N.Y. Times, Nov. 4, 1961, p. 20, col. 2.

31. See Civil Rights Report 143.

32. 71 Stat. 634 (1957), 42 U.S.C. \& 1971 (1958). The purpose of the bill was "to provide means of further securing and protecting . . . civil rights." House RePORT at 1966. The constitutionality of 42 U.S.C. $\$ \S 1971$ (a) \& (c) was established in United States v. Raines, 362 U.S. 17 (1960). The constitutionality of 42 U.S.C. $\$ 1971$ (b) can be implied from the statement of Mr. Justice Brewer in James v. Bowman, 190 U.S. 127 (1903), that if $\S 5$ had been limited to federal elections (as $\S 1971$ (b) is) it would have been constitutional.

33. 71 Stat. 637 (1957), 42 U.S.C. \$ 1971(b) (1958).

34. 71 Stat. 637 (1957), 42 U.S.C. \& 1971 (c) (1958).

35. 71 Stat. 637 (1957), 42 U.S.C. \& 1971(d) (1958).

For a discussion of these and other sections of the Civil Rights Act of 1957 see House Report; Comment, 43 CoRnell L.Q. 661 (1958) ; Lane, The Civil Rights Act of 1957, 4 Howard L.J. 36 (1958); Comment, 56 MrCH. L. Rev. 619 (1958).

The Civil Rights Act of 1960, 74 Stat. 86, was aimed at curing some defects in the Civil Rights Act of 1957 and to assist in the implementation of the prior act. See Crvm. Rigurs REPORT 76-78. 
In United States v. Beaty, ${ }^{36}$ the Attorney General invoked the 1957 act for the first time to protect Negro voting rights against economic coercion by private citizens. ${ }^{37}$ The case arose in Haywood County, Tennessee, ${ }^{38}$ one of the "black belt" counties in which no Negro had been registered to vote since the period of Reconstruction..$^{39}$ Inspired by the efforts of the newly formed Civic and Welfare League of neighboring Fayette County to increase Negro registration, some Haywood County Negroes initiated a similar effort. ${ }^{40}$ The white businessman retaliated by circulating a "black list" composed of Negroes who registered and whites who assisted them. ${ }^{41}$ All local merchants were "induced" to boycott anyone whose name appeared on the list by denying him credit, refusing to sell him necessities or other goods even for cash,

36. 288 F.2d 653 (6th Cir. 1961).

37. 42 U.S.C. $\$ 1971$ (b). There was one other prosecution under this subsection of the Act. After Mr. Francis Joseph Atlas of East Carroll Parish, La., had testified before the United States Commission on Civil Rights, Hearings before the United States Commission an Civil Rights 24-27 (1961), he informed the Commission that as a result of his testimony he was being subjected to an economic boycott. See Time Magazine, Sept. 15, 1961, p. 24. As a result of his complaints, the Department of Justice filed a suit under $\S 1971$ (b) on his behalf. Hcarings 793-99. In February of 1961, the white defendants agreed to carry on business with Mr. Atlas and not to "intimidate, threaten, coerce ... the said Francis Joseph Atlas for the purpose of interfering with the right of the said Francis Joseph Atlas to vote...." Stipulation in the case of United States v. Deal, reported in Hearings 799-800. The Justice Department said the agreement was the first in an economic reprisal case. See Birmingham News, Feb. 5, 1961, p. 31a.

38. Subsequently, an identical action was brought in adjacent Fayette County, Tennessee. The district court granted a temporary restraining order against landlord defendants in the Fayette County suit and the order has been understood by the parties to be effective pending the outcome of the Haywood County suit. See Civil RIGHTs Report 96.

39. See Civil Rights Report 37, 284-85, 348.

40. The problem in these Western Tennessee counties started when Negroes in Fayette County became dissatisfied with the manner of law enforcement in the county and decided to take a hand in the primary election for sheriff held on August 1, 1959. See Ebony Magazine, Sept. 1960, p. 30. In May of that year J. F. Estes, a Memphis attorney, organized the Fayette County Civic and Welfare League. See Dykeman and Stokely, The Big Cure for Segregation, N.Y. Times, Sept. 24, 1961, p. 104 (Magazine Section). Mr. Estes formed a similar organization in Haywood County. Ibid. There were at that time about 600 Negro voters in Fayette County. See Ebony Magazine, Sept. 1960, p. 30. On primary day, the Negroes in Fayette County were barred from the polls. The government brought an action under $\$ 1971$ (a) seeking to enjoin the white primary, which suit ended in a consent decree. United States v. Fayette County Democratic Executive Committee, Civil No. 3835 (W.D. Tenn. 1959). After the white primary was outlawed in Fayette County, Negroes began registering by the hundreds. See Time Magazine, Jan. 6, 1961, p. 22. In Haywood County, Negro efforts to register were subjected to a series of dilatory tactics. See Brief for Appellant, pp. 5-6, United States v. Beaty, 288 F.2d 653 (6th Cir. 1961) [hereinafter cited as Government Brief] ; Dykeman and Stokely, supra at 104.

41. See Government Brief, pp. 4-11. "The real fight began with signals being called by the White Citizens Council which meets, reportedly, in the Courthouse. At a meeting there last April, the blacklist was drawn up. A dozen Negro leaders were used as a basic list and others were added as they registered to vote .... [It] appears, there are at least a dozen white men being boycotted, along with about 400 Negroes." Ebony Magazine, Sept. 1960, p. 32. 
and terminating his employment. ${ }^{42}$ When Negro tenants on the sharecropping farms also began to register, ${ }^{43}$ the white landowners countered by refusing to renew their sharecropping contracts and evicting or dismissing registered Negroes. ${ }^{44}$ The evicted Negroes moved into a makeshift tent city on the farm of a Negro landowner, ${ }^{45}$ and were supplied with necessities by outside persons and the federal government. ${ }^{46}$

The government brought suit against certain Haywood County landowners and businessmen praying for both permanent and temporary orders enjoining the alleged acts. ${ }^{47}$ In addition, the government asked the court to order the defendant landlords to file explanatory affidavits before they could evict Negro sharecroppers or alter their contracts. ${ }^{48}$ After a preliminary hearing the district court temporarily restrained thirteen businessmen defendants from "interfering through intimidation and/or coercion in registration . . .."40

42. See complaint reported in Appendix to Government Brief, pp. 7a-8a, United States v. Beaty, 288 F.2d 653 (6th Cir. 1961). 109.

43. See Ebony Magazine, Sept. 1960, pp. 30-32; Dykeman and Stokely, supra note 40 at

44. When the cotton harvest ended, the sharecroppers who had registered were ordered to move on. Time Magazine, Jan. 6, 1961, p. 22. Many of these sharecroppers issued affidavits as to the reason for their eviction. See Appendix to Government Brief, pp. 25a-100a, United States v. Beaty, 288 F.2d 653 (6th Cir. 1961).

45. The evicted Negroes moved not out of the county, but onto property owned by a Negro landowner, Shepherd Towles. Time Magazine, Jan. 6, 1961, p. 22. Immediate tension began to mount with the erection of this tent city, dubbed "Freedom Village" by its sponsors and "a publicity stunt to attract sympathy for the Negroes" by its opponents. See Christian Science Monitor, Jan. 6, 1961, § 1, p. 4.

46. Many outside persons and organizations contributed to the support of the Negroes in the tent city. N.Y. Times, Dec. 30, 1960, pp. 1, 5; Shreveport Times, Jan. 14, 1961, editoria1; Detroit News, Feb. 5, 1961, § A, p. 6 (five University of Michigan students went to the tent city in order to distribute food and were asked to leave the county by the sheriff).

47. On September 13,1960, the Department of Justice brought an action under $\$ 1971$ (b) against 29 white persons in Haywood County. This was increased to 65 by amendment on November 18, 1960. On December 14, 1960, a second suit on the same grounds was filed in Fayette County. See N.Y. Times, Sept. 15, 1960, p. 34m ("If the Justice Department can win this injunction and make it stick, it will have opened up a new avenue in the long struggle to bring voting equality to the Negro citizen. One of the cruelest and most effective weapons used to deprive him of his rights has been the economic weapon, against which he has been powerless to defend himself unaided."); Baltimore Afro-American, Sept. 20, 1960, p. 4 ("The law suit filed, last week, by the U.S. Attorney General . . could be the most significant move by the Federal Government since the Supreme Court's desegregation ruling, May 17, 1954") ; compare Shreveport Times, January 14, 1961 ("So, here we find a federal court raising the issue that a man who has been in a sharecropping agreement with another man in the past must continue that sharecropping agreement indefinitely-perhaps foreverbecause at some time or other he expressed the view that he wouldn't have Negro voters as his partners in crop production.").

48. See Reply Brief for Appellant, p. 7, United States v. Beaty, 288 F.2d 653 (6th Cir. 1961) [hereinafter cited as Reply Brief].

49. The opinion is not reported. See copy in Appendix to Government Brief, pp. 395a400a, United States v. Beaty, supra note 48; Reply Brief, pp. 2-3; cf. Shreveport Times, supra note 47. 
But it refused to enjoin the landowners from evicting registered Negroes, reasoning that the Civil Rights Act did not vest it "with authority to adjudge contracts and property rights." "wo It, therefore, denied all government prayers "relative to the eviction of tenants," including the request for affidavits. ${ }^{51} \mathrm{On}$ appeal, the Sixth Circuit extended the restraining order to apply to the landlords " ${ }^{62}$ but affirmed the district court's denial of the request for affidavits, because "the request would assume that the defendant did violate the law and place upon him the burden to prove that he did not." "53

The circuit court's construction of the 1957 act to apply to economic coercion in general and to economic coercion involving contract and property rights in particular seems correct. In requesting legislation to protect voting rights, President Eisenhower noted: "It is disturbing that in some localities allegations persist that Negro citizens are being deprived of their right to vote and are likewise being subjected to unwarranted economic pressures."54 Senator Douglas, a sponsor of the bill, asserted that the legislation was directed at denials of voting rights "by economic pressure" as well as by other means. ${ }^{\text {"S }}$ And Representative Celler, a House sponsor, indicated that if "the milk dealer, the coal dealer, the butcher, the baker, and the candlestick maker ... agree . . . to boycott" persons who try to vote, the agreement would violate the proposed law. ${ }^{56}$ Since economic coercion may be accomplished by the improper exercise of contract and property rights as well as by refusals to sell, and since Congress apparently recognized this obvious fact, the district court had no ground, in the absence of a specific statutory exclusion, for creating a verbal distinction which could effectively defeat the manifest purpose behind the legislation.

Both courts were correct in holding that the 1957 act permitted the granting of preliminary orders temporarily restraining interferences with voting rights, ${ }^{, 7}$ since the statute specifically empowers the district court to grant "preventative relief" including temporary restraining orders. ${ }^{58}$ And they were correct in holding that the facts of this case demanded such relief. If during the course

50. See Appendix to Government Brief, p. 398a, United States v. Beaty, 288 F.2d 653 (6th Cir. 1961).

51. Id. at 399a.

52. United States v. Beaty, 288 F.2d 653, 657-58 (6th Cir. 1961).

53. Id. at 656-57.

54. "State of the Union Message," sent to Congress January 5, 1956, reprinted in U.S. Code Congressional and Administrative News, 84th Cong., 2d Sess. 4657, 4668 (1956).

55. 103 Cong. Rec. 10988 (1957).

Instances of economic coercion were incorporated into the record by several Congressmen. See, c.g., 103 Cong. Rec. 12793-97 (1957) (“. . . many landlords reportedly have warned their Negro tenants that if they registered they would be fired."); id. at A1741; id. at 12902-03.

56. Hearings 45 . The words are from the question by Chairman Smith to witness Celler during an extended colloquy between the two. See generally id. at 41-46.

57. See notes $49 \& 52$ supra.

58. 42 U.S.C. $§ 1971$ (c) (1958). 
of the litigation defendants could force the Negroes to choose between voting and their livelihood, the injury resulting from either course would probably be irreparable, because even a successful trial could not restore the right to vote in a past election nor could it return the enjoyment of past necessities which probably have been foregone. Moreover, a preliminary injunction would alleviate some of the disruptive effects of the suit; unlawful dismissals would not occur at least during the litigation, and fewer dismissals of sharecropper replacements ${ }^{59}$ would thus be necessary if and when the government prevailed.

In the trial "on the merits" which will now be conducted, ${ }^{60}$ the district court will be asked permanently to enjoin businessmen and landlords from conditioning economic transaction upon the voting status of the customer, employee or tenant. ${ }^{61}$ Although at common law a businessman or a landowner had the privilege of refusing to deal with a particular person for any reason, ${ }^{62}$ cases upholding the right of the federal government to proscribe certain anticompetitive refusals to deal, ${ }^{63}$ and to regulate the landlord-tenant relationship in order to effectuate a national purpose ${ }^{64}$ indicate that Congress has the power to qualify these common law privileges. And since Congress has, by statute, ${ }^{05}$

59. See note 71 infra.

60. See Civil Rights Report 96.

61. See Reply Brief, p.7.

62. See Note, 45 ILL. L. Rev. 784, 785 (1951); Hamilton, Property Rights in the Market, 1 J. LEG. \& PoL. SocroL. 10 (1931).

63. These Sherman Act, 15 U.S.C. $\S \S 1,3,4$ (1958) cases involve the problem of a seller trying to enforce a policy of resale price maintenance by refusing to deal with price cutters. See Neale, The Antr-Trust Laws of the U.S.A. 340-45 (1960). The problem was stirred up when Mr. Justice McReynolds decided a case on a procedural point, but went on to say, by way of dictum, that "in the absence of any purpose to create or maintain a monopoly, the act does not restrict the long recognized right of trader or manufacturer engaged in an entirely private business, freely to exercise his own independent discretion as to parties with whom he will deal." United States v. Colgate \& Co., 250 U.S. 300, 307 (1919). Even here, however, it is to be noted that Mr. Justice McReynolds stated that this right was not unqualified.

The effect of this observation was whittled down in a series of subsequent decisions. United States v. Schrader's Son, Inc., 252 U.S. 85 (1920) ; Frey \& Son, Inc. v. Cudahy Packing Co., 256 U.S. 208 (1921) ; FTC v. Beech-Nut Packing Co., 257 U.S. 441 (1922); United States v. Bausch \& Lomb Optical Co., 321 U.S. 707, 722 (1944); United States v. Parke, Davis \& Co., 362 U.S. 29 (1960). This last case may have overruled Colgate altogether. See $i d$. at 49 (concurring opinion of Stewart, J.) and ibid. (dissenting opinion of Harlan, J.).

64. See 2 Powell, Real Property 352-71 (1950). Under this form of legislation the federal government, the states, and the municipalities have been able to regulate the landlord tenant relationship. When a tenant remains in possession after the expiration of the original relationship, for example, the ensuing tenancy is termed a "statutory tenancy" and its duties and obligations are governed by the prior leasing contract. Id. at 371. The constitutionality of this rent control legislation was upheld in Bowles v. Willingham, 321 U.S. 503 (1944). See also Willis, A Short History of Rent Control Laws, 36 CorNeLL L.Q. 54 (1950); Weiss, Good Faith and Eviction Control, 60 YALE L.J. 600 (1951).

65. 42 U.S.C. $\$ 1971$ (b) (1958). 
declared interference with voting rights to be an illegal reason for refusing to deal, ${ }^{00}$ the district court is clearly empowered permanently to enjoin both the businessman and the landowner from employing such coercion.

Since many individuals may be adversely affected in a variety of ways by these requested permanent orders, it may be argued that the district court should decline to exercise its power to grant such equitable relief. ${ }^{67}$ An order requiring businessmen to treat Negroes who had registered in the same fashion as Negroes who had not registered would certainly engender some hostility. But since the boycott apparently has been imposed upon some businessmen involuntarily, and since it has been costly to all the local businessmen, ${ }^{\text {ss }}$ the reactions accompanying a federal order enjoining the continuation of the boycott would probably not be unmixed. The assessment of money damages, the only real alternative device which could be employed in lieu of an injunction, would provide less than adequate relief. In a suit for damages, the plaintiff must show specific economic injury, ${ }^{69}$ whereas in a suit for injunction plaintiffs need only prove that the actions of defendants interfered with voting rights. Moreover, even if substantial money damages were assessed by the local jury, more hostility might be engendered than if an injunction were ordered, for the damages would likely be assessed against the very businessmen who were incurring losses as a result of the boycott. A permanent order enjoining the local businessmen from boycotting registered Negroes would therefore best effectuate the enforcement of Negro voting rights at the least social cost.

But since in a rural setting landlord-tenant and employer-cropper relations are far more intimate than the relatively impersonal seller-buyer relation, permanent relief requiring reinstatement of Negro tenants or employees evicted or dismissed for attempting to register raises more serious problems than the requirement of selling without regard to registration status. A court order compelling landlords or employers to take back old tenants or employees, in addition to requiring two groups to work or live together in an atmosphere of belligerence, may harm innocent third parties; for the order would result in the eviction or dismissal of any sharecroppers who replaced the previously evicted Negroes. ${ }^{70}$ But if these replacements knew that they were being hired to thwart the efforts of others to vote, their claim of injury carries less weight. Indeed, the fact that the federal government had instituted proceedings and that the evicted or dismissed Negroes were encamped in a nearby

66. See notes 54-56 supra and accompanying text.

67. See 4 Poxieroy, Equity Jurisprudence $\$ 1338$ ( 5 th ed. 1941).

68. See Ebony Magazine, Sept. 1960, pp. 27-30. See note 72 infra.

69. Otherwise the successful plaintiff will only receive nominal damages.

70. But the labor cases have held that the fact that reinstatement might mean dismissal of replacements is no excuse for not reinstating. See, e.g., NLRB v. Pecheur Lozenge Co., 209 F.2d 393, 404-05 (2d Cir. 1953) ; NLRB v. Remington Rand, Inc., 130 F.2d 919 (2d Cir. 1942). 
"tent city" anticipating return to their farms, should have caused the replacements to anticipate a tenure of uncertain duration.

Balanced against these costs, there are important advantages to be obtained by ordering reinstatement. Most important, reinstatement is necessary if Negro tenants or employees unlawfully evicted or dismissed are to be made whole. ${ }^{71}$ Reinstatement, moreover, may deter landlords or employers from similar wholesale evictions and dismissals in the future, because unlike the outcomes of successful criminal or damage actions, the violator cannot rid himself of those unlawfully dismissed at any price. ${ }^{72}$ The threat of reinstatement would also tend to reduce the incidence of economic pressures being unlawfully exerted upon reluctant landlords and businessmen to evict or dismiss Negro registrants. ${ }^{73}$

However appropriate reinstatement may appear in response to the allegedly unlawful evictions or dismissals in Beaty, courts of equity have traditionally been reluctant to order this remedy. ${ }^{74}$ Some courts have characterized the landlord-sharecropper relationship as that of landlord and tenant ${ }^{75}$ since the

71. It is clear that without reinstatement the Negro will suffer severe disruption because of his attempt to vote. "The victims themselves are profoundly injured by the expense and inconvenience of moving-if they can find new farms. Their children's schooling is disrupted. Even those who remain are being irreparably injured because they are deprived of their federal statutory right to be free from attempts to intimidate them." Reply Brief at 9.

72. A successful action in Haywood County may deter landholders in other counties from similar conduct. A farmer who illegally evicts his croppers will suffer the disruption of getting a new tenant, the expense of a protracted law suit, and, after losing the trial on the merits, an injunction commanding reinstatement. The net effect will be greatly to disturb the economy of the county, and businessmen and farmers of these not too prosperous "black belt" counties may be hesitant to make a similar attack on Negro voting when in all probability their efforts will only achieve a bitter and expensive return to the status quo ante.

73. It was reported that when many of the white landlords asked their tenants to move on, they stated that they had to do this because of pressure on them. See, e.g., Appendix to Government Brief, pp. 30a-31a, United States v. Beaty, 288 F.2d 653 (6th Cir. 1961) ("Mr. Gillespie said he wished he had had a chance to talk to me. He said, 'You know if the white people up town tell me I got something on my place that isn't right, I will know what it is, and if the white say I have, I will sow my farm down in Bermuda grass and move to town." ").

74. The early common law had an expansive view of freedom of contract, and because of arguments like lack of mutuality of remedy in a personal service contract, it refused to grant specific performance for employment contracts. See, e.g., Union Labor Hospital Ass'n v. Vance Redwood Lumber Co., 158 Cal. 551, 554, 112 Pac. 886 (1910) ("Precisely as may the employee cease labor at his whim or pleasure, and, whatever be his reason, good, bad, or indifferent ... so, upon the other hand, may the employer discharge, and, whatever be his reason, good, bad, or indifferent, no one has suffered a legal wrong.") ; Lambert v. Georgia Power Co., 181 Ga. 624, 183 S.E. 790 (1936) ; 5 CorbIN, Contracts \$ 1204 (1951).

75. The difference between the two is verbal: if the landlord receives his share of the crop as rent, then there is a landlord-tenant relation; but if the share of the produce the cropper keeps is considered salary, then there is an employer-employee relation. Important legal consequences, however, flow from this characterization. See 1 TrFFANY, REAL Property \& 78 (3d ed. 1939). 
tenant has an interest in land which is considered inherently unique, his remedy at law will usually be inadequate ;6 $^{76}$ he may therefore obtain injunctive relief for possession. ${ }^{77}$ But other courts have labeled the relationship one of employer and employee; and at common law, either could terminate an employment contract at will, risking only an action for damages. ${ }^{78}$ Even if this view of the relation is accepted, Congress has the power to alter common law doctrine. ${ }^{78}$ The Supreme Court has, for example, upheld the Wagner Act section which provides for reinstatement of employees whose dismissal constituted an unfair labor practice. ${ }^{80}$ The Court has upheld reinstatement

76. See 4 Podreroy, EQuity JuRISPRUdence $\$ 1402$ (5th ed. 1941).

77. See, c.g., Jackson v. Bowlin, 11 Okla. 299 (1925); cf. Kelley v. Moody, 176 Ga. 138,167 S.E. 10 (1932).

78. See, e.g., Nicholson v. Cook, 76 Ga. 24 (1885).

79. This was not always so certain. The State and Federal legislatures were rebuffed when they first attempted to change the common law. Coffeyville Vitrified Brick \& Tile Co. v. Perry, $69 \mathrm{Kan} .297,300,76 \mathrm{Pac} .848$ (1904) ("Any act of the legislature that would undertake to impose on an employer the obligation of keeping in his service one whom, for any reason, he should not desire would be a denial of his constitutional right to make and terminate contracts and to acquire and hold property") ; State ex rel. Zillmer v. Kretuetzberg, 114 Wisc. 530, 545, 90 N.W. 1098 (1902).

When Congress attempted to make it a crime to discharge employees because of their activities in labor organizations, the Supreme Court held that any legislation that disturbs the equality of employees' and employers' right to contract was an arbitrary interference with the liberty of contract "which no government can legally justify in a free land." Adair v. United States, 208 U.S. 161, 175 (1908). The Court, however, did recognize the fact that there might be some restriction on freedom of contract when it said, "Such liberty and right embrace the right to make contracts for the purchase of the labor of others ... subject to the fundamental condition that no contract, whatever its subject matter, can be sustained which the law, upon reasonable grounds, forbids as inconsistent with the public interests, or as hurtful to the public order, or as detrimental to the common good." Id. at 172. A condition in an employment contract that the employee not join a union was not a condition that the legislature could forbid in order to protect the common good. Coppage v. Kansas, 236 U.S. 1, 10-11 (1915).

For the modern renunciation of this position see note 80 infra.

80. When the Wagner Act was upheld in NLRB v. Jones \& Laughlin Steel Corp., 301 U.S. 1 (1937), the power of the employer to fire an employee for joining a union was restricted. Section 10(c) of the Wagner Act, 29 U.S.C. $\$ 160$ (c) (1958), provides for the reinstatement of an employee who was discharged from his employment because of union affiliation. There is no elaborate background to the notion of job reinstatement. It is a common sense device that had formerly been used by the old Labor Board under P.R. 44 . See Phelps Dodge Corp. v. NLRB, 313 U.S. 177, 187-88 (1941).

Once recognizing the right of the legislature to grant reinstatement, the courts have been vigilant in protecting it. It has been held that this right can not even be contracted away by the employee. NLRB v. American Potash \& Chem. Corp., 113 F.2d 232 (9th Cir. 1940) ; Waterman S.S. Co. v. NLRB, 119 F.2d 760 (5th Cir. 1941).

Moreover, statutes have been upheld which have restricted the right of the employer to fine an employee for participating in activities unrelated to employment. In Lockheed Aircraft Corp. v. Superior Court of Los Angeles County, 28 Cal.2d 481, 171 P.2d 21 (1946), an employer had allegedly wrongfully discharged an employee because of his political activities. The employer challenged the constitutionality of the statute, § 1101 of the 
orders, even in the absence of a specific statutory provision, when necessary to effectuate the purpose of a labor statute. ${ }^{81}$ And at least two courts have ordered reinstatement to further "public policy" expressed in statutes unrelated to labor regulation. ${ }^{82}$ Since the 1957 Civil Rights Act was aimed at economic coercion, and since reinstatement would most effectively further the "public policy" embodied in the act, this rationale seems particularly appropriate to the situation in Beaty.

The government's request that defendants be ordered to file sworn state-

CAL. LABOR CODE, which forbade employers from interfering in the political activities of their employees. The court upheld the restriction on the employers' right to discharge. Kouff v. Bethlehem-Alameda Shipyard Inc., 90 Cal. App. 2d 322, 202 P.2d 1059 (1949), involved an employee who was discharged from employment because he absented himself from his job to serve as an election official in accordance with $\$ 695$ of the CAL. ELECTION Cone. In finding for Mr. Kouff the court said: "Granting that under the general law an employee at will may be discharged without any cause, this particular statute interposes an exception to that rule, the basis of which is the necessity of drawing on industry for such temporary public servants as election officers." Id. at 325. Compare Mallard v. Boring, 46 L.R.R.M. 2862 (Cal. Dist. Ct. App. 1960) where the court held there was no statute protecting the right to be a juror.

81. Railway Labor Act. Texas \& N.O. R.R. v. Brotherhood of Ry. \& S.S. Clerks, 281 U.S. 548 (1930). See Phelps Dodge Corp. v. NLRB, 313 U.S. 177, 188 (1941) ("Therefore, if $\S 10$ (c) had empowered the Board to 'take such affirmative action as will effectuate the policies of this Act,' the right to restore to a man employment which was wrongfully denied him could hardly be doubted.").

82. Petermann v. Local 396, International Bhd. of Teamsters, 44 L.R.R.M. 2968 (Cal. Dist. Ct. App. 1959), 174 Cal. App. 2d 184, 344 P.2d 24 (1959), involved a union business agent, employed on a contract terminable at will, who was fired allegedly for refusing to commit perjury before a state legislative hearing. The commission of perjury and the solicitation of the commission of perjury are crimes. CAL. PENAL CoDE $\$ \S 118,653(f)$. The court held for the agent.

The threat of criminal prosecution would ... be a sufficient deterrent .... However, in order to more fully effectuate the state's declared policy against perjury, the civil law, too, must deny the employer his generally unlimited right to discharge an employee whose employment is for an unspecified duration, when the reason for the dismissal is the employee's refusal to commit perjury. . . . To hold that one's continued employment could be made contingent upon his commission of a felonious act at the instance of his employer would be to encourage criminal conduct . . . and would serve to contaminate the honest administration of public affairs."

Id. at 2969-70. The case is noted in 14 VAND. L. Rev. 397 (1960) ; 14 Rutgers L. Rev. 624 (1960).

The other case, Bussell v. Bishop, 152 Ga. 428, 110 S.E. 174 (1921), involved a landlord who frightened a cropper off of the farm in mid-season. The court permitted the cropper to return to gather the crops.

While the solvent landlord may not be enjoined from breaching his contract with his cropper, and from entering into and taking possession of the crop, though wrongfully, the solvent landlord has no ... right to compel the cropper to abandon his crop .... [T] he judge was authorized ... to issue an injunction against the landlord, though solvent, restraining him from going upon and taking charge of the crops....

Id. at $430-31$. 
ments of the reasons for subsequent evictions, dismissals, or contract adjustments "involving any Negro of voting age in Haywood County" was rejected by both courts. ${ }^{83}$ The Sixth Circuit's objection that this procedure presumes violation, placing an unfair burden of proof on defendants, ${ }^{84}$ is unconvincing because all preliminary orders assume temporarily that the defendants are behaving unlawfully ; $;$ and while the affidavits may require the defendant to come forward with some explanation for his action, the burden or proof in any subsequent contempt proceedings remains with the government. Nevertheless, the government's request that defendants affirmatively set forth the reasons for taking action against Negroes, may have gone too far. The government has no legitimate interest, under the statute, in discovering why a given Negro was evicted, except to determine whether or not the eviction was related to voting rights. But the requested affidavit would enable the government to commence perjury or contempt ${ }^{86}$ proceedings against a defendant who, for example, had sworn that he evicted a tenant because of laziness when the eviction was in fact based on a desire to mechanize. This defect could be remedied simply by requiring, as a condition to eviction of any voting age Negro, an affidavit stating that the tenant's voting status played no part in the decision to dismiss.

The government's objective in requesting the affidavits may have been the notice it would receive of contemplated actions concerning voting age Negroes $;^{87}$ such notice would afford the government an opportunity to investigate the circumstances and oppose the action if it were actually an attempt to interfere with voting rights. Although even absent the affidavits, subsequent contempt proceedings could be employed to punish landowners who evicted registered Negroes for disengenuous reasons, 88 conditioning eviction upon

83. United States v. Beaty, 288 F.2d 653, 657 (6th Cir. 1961).

84. Ibid.

85. They do so at least in the sense that they prohibit certain of the defendant's activities. See Pomerox, EQUity Jurisprudence $\$ \$ 1359-1359$ a (5th ed. 1941).

86. The use of injunctive relief brings into play the contempt power of the federal court to protect its decrees. See Comment, 43 CoRnell L.Q. 661 (1958); cf. Comment, 65 Y ALE L.J. 630 (1956).

87. Alternatively, it might just be an attempt to gain information. Because the very same actions that the government sought to obtain civil relief also give rise to criminal prosecution, 18 U.S.C. $\$ 594$ (1958), the government's efforts in obtaining full information from both sides were hindered. The white defendants refused to answer most of the government's questions during the district court hearings on the grounds that any answer that they might give might tend to incriminate them. See generally Appendix to Government Brief, pp. 290a-292a, 304a-305a, 312a-314a, 319a-320a, 325a-327a, 332a-335a, 401a-425a, United States v. Beaty, 288 F.2d 653 (6th Cir. 1961). It would seem both fairer to the defendants in such a civil action and a possible assistance in government fact finding if an amendment were added to 42 U.S.C. $\S 1971$ (c) (1958) to the effect that by bringing a civil action the government precluded itself from bringing a criminal action on the same set of facts.

88. The court thought this would be a sufficient deterrent. United States v. Beaty, 286 F.2d 653, 658 (6th Cir. 1961). 
the submission of an affidavit (or some other reliable method of notification) may be the only effective "preventative relief" the court could grant to assure that no coercion was employed. An affidavit stating that voting status played no part in the decision would certainly suffice for this purpose.

If adequate care is given to fashioning both temporary and permanent orders, the 1957 Civil Rights Act seems adequate to combat blatant instances of economic coercion such as those alleged in Beaty. But where the violations are less obvious, the government may have difficulty in proving intent to interfere with voting rights; since Negroes are typically at the bottom of the economic ladder, there are frequently credible business reasons for severing economic relations with some of them. ${ }^{89}$ Widespread use of the 1957 act is certain to engender increased animosity between all the parties affected. While such an atmosphere may be a necessary cost of securing Negro voting rights, it indicates that ultimate solution to the problem cannot be achieved by legal means alone; those institutions which influence social attitudes have also to play a crucial role. ${ }^{80}$

89. See Baltimore Afro-American, Sept. 20, 1960, p. 4.

90. Civil Rights Report at 197; Time Magazine, Sept. 15, 1961, p. 25 ; N.Y. Times, Sept. 15, 1960, p. 34m. 